Check for updates

Cite this: RSC Adv., 2017, 7, 36844

\title{
Synthetic studies en route to the first total synthesis of a naturally occurring quinone from Acorus gramineus, iso-merrilliaquinone, iso-magnoshinin and 2-epi-3,4-dihydro magnoshinin $\dagger$
}

\author{
Dileep Kumar, Oindreela Das, Manvendra Singh Kaurav and Tabrez Khan (DD *
}

Received 7th May 2017

Accepted 18th July 2017

DOI: $10.1039 / \mathrm{c} 7 \mathrm{ra05148d}$

rsc.li/rsc-advances

\begin{abstract}
A unified synthetic strategy based on [4 +2 ] cycloaddition of readily accessible coupling fragments was conceptualized for the racemic total synthesis of recently isolated bioactive merrilliaquinone and other closely related quinones such as gramineusquinone B as well as neolignan, magnoshinin. The present article discloses our efforts in this direction which culminated in the total syntheses of gramineusquinone B, iso-merrilliaquinone, iso-magnoshinin and 2-epi-3,4-dihydro magnoshinin.
\end{abstract}

\section{Introduction}

Illicium merrillianum is a small tree or shrub which is endemic to southwestern China and Burma. Besides using the bark, root bark and fruit of this shrub in Traditional Chinese Medicine (TCM) for treating rheumatism, ${ }^{1}$ it is also found to possess a vast plethora of structurally diverse and unique bioactive natural products. ${ }^{2}$ Since the onset of the $21^{\text {st }}$ century, Fukuyama and co-workers have been actively engaged in the isolation and bioactivity screening of several anislactone-type sesquiterpenes, allo-cedrane-type sesquiterpenes and seco-prizizaane type sesquiterpenoids from I. merrillianum and other Illicium species. ${ }^{2}$ Indeed, their pioneering efforts in this arena led to the discovery of potent neurite outgrowth promoters such as merrilactone $\mathrm{A},{ }^{3}$ 11-O-debenzoyl tashironin ${ }^{4}$ and jiadifenolide ${ }^{5}$ which garnered significant world-wide attention from the scientific community ${ }^{6-8}$ with the scope of their application in treatment of neurodegenerative diseases such as Alzheimer's and Parkinson's.

Further, in continuous pursuit for new bioactive compounds as potential leads for drug discovery, very recently Zhang et al. got interested in exploring the leaves and branches of $I$. merrillianum which ended up with the isolation of some unique abietane diterpenoids ${ }^{9}$ as well as some bioactive quinoid natural products. ${ }^{10}$ Perhaps, it was the bioactivity of the $(+)$ antipode of merrilliaquinone (1), Fig. 1, reported by them and accessed via chiral HPLC separation from the racemic natural product that caught our attention. Interestingly, the $(+)$ antipode of merrilliaquinone was found to be several fold more

Organic Synthesis Laboratory, School of Basic Sciences, Indian Institute of Technology Bhubaneswar, Argul, Jatni-752050, Odisha, India.E-mail: tabrez@iitbbs.ac.in; Tel: +91706 4419592

$\dagger$ Electronic supplementary information (ESI) available. CCDC 1548143. For ESI and crystallographic data in CIF or other electronic format see DOI: 10.1039/c7ra05148d potent and selective towards human hepatoma cells over normal hepatic cells in comparison to the $(-)$ antipode or the racemic form of the natural product. ${ }^{10}$ Another, interesting fact related to $\mathbf{1}$ is, it was also reported in the racemic form by $\mathrm{Lu}$ et al. as acortatarinowin $\mathrm{H}$ from the rhizomes of Acorus tatarinowii Schott just after the report by Zhang et al. ${ }^{11}$ Further, we were pleasantly surprised to learn that there exist structurally closely related quinones such as $\mathbf{2 - 4}$ and neolignans $\mathbf{5 , 6}$ as captured in Fig. 1, all having their origins from herbs used in TCM. For instance, quinones 2 and 3 were of late isolated in optically pure form from the rhizomes of Acorus gramineus, and reported to exhibit decent anti-inflammatory as well as cytotoxicity against certain human cancer cell lines. ${ }^{12}$ For convenience sake, we have preferred to refer them as gramineusquinone A and B respectively instead of the conventional
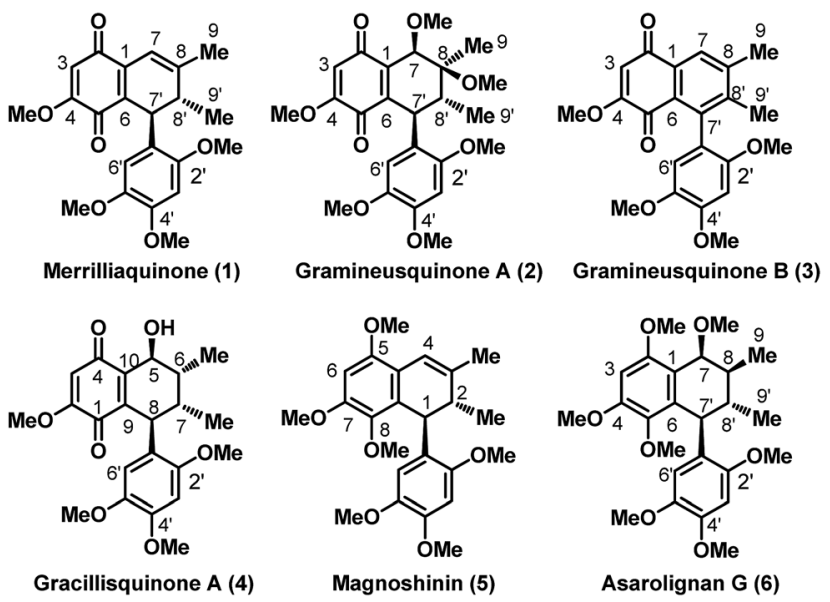

Fig. 1 Representative examples of bioactive quinones and neolignans isolated from herbal plants used in Traditional Chinese Medicine (TCM) [indicated numbering as per the isolation paper]. 
name assigned by Lee. et $a .^{\mathbf{1 2}}$ On the other hand, with no bioactivity so far reported gracillisquinone (4) was isolated not long ago from Spallerocarpus gracilli. ${ }^{13}$ While among the neolignan 5 and 6, magnoshinin with prominent anti-inflammatory activity was reported in 1983 after its isolation from the flower buds of Magnolia salicifolia, more famous as "Shin-i" in TCM. ${ }^{14}$ Whereas, asarolignan G (6) with anti-neuroinflammatory activity is a very recently surfaced neolignan from the rhizomes of Acorus tatarinowii. ${ }^{\mathbf{1 5}}$

The impressive bioactivity profile exhibited by 1 though in one of its enantiomeric pure form, as well as close structural resemblance with quinones $\mathbf{2 - 4}$, together with a strong prospect to elaborate them to neolignans $\mathbf{5}$ and $\mathbf{6}$ engaged our interest towards these natural products. Further, the fact that except for 5 (ref. $16 a-c$ ) there exists no synthetic endeavors towards any of these natural products motivated us to embark on a synthetic journey directed towards the racemic total syntheses of these bioactive quinones and neolignans to access them in substantial quantities for thorough clinical assessment. Moreover, initially we aimed to develop a concise unified approach based on $[4+2]$ cycloaddition strategy taking inspiration from our earlier success in application of similar approach in context of syntheses of quinoid natural products such as acremine $\mathrm{G}^{\mathbf{1 7}}$ and allomicrophyllone. ${ }^{18}$

\section{Results and discussion}

To test the viability of the approach we had in mind, we initially chose to focus on the development of a racemic synthesis for $\mathbf{1}, \mathbf{3}$ and 5 before targeting other interested natural product depicted in Fig. 1. In this context, our retrosynthetic plan is as outlined in
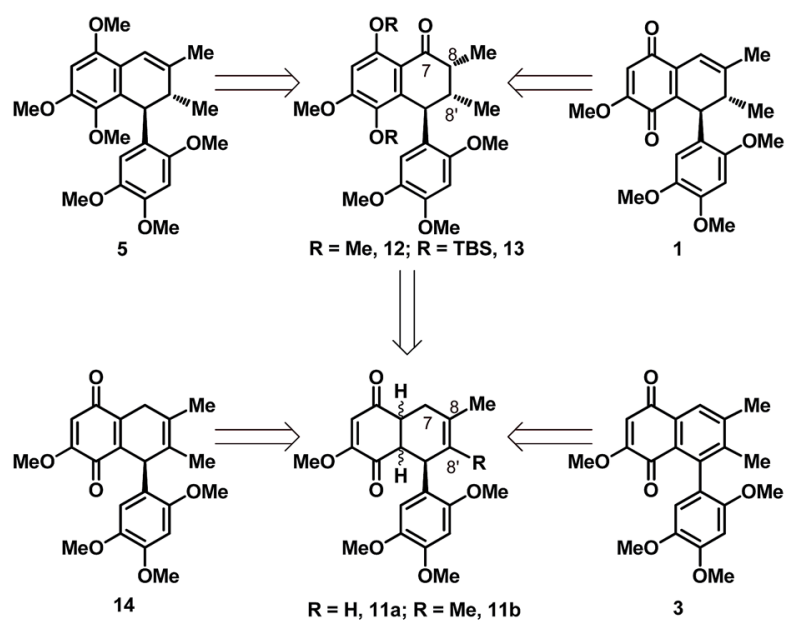

$\downarrow$<smiles>C1=CCCCC=C1</smiles>
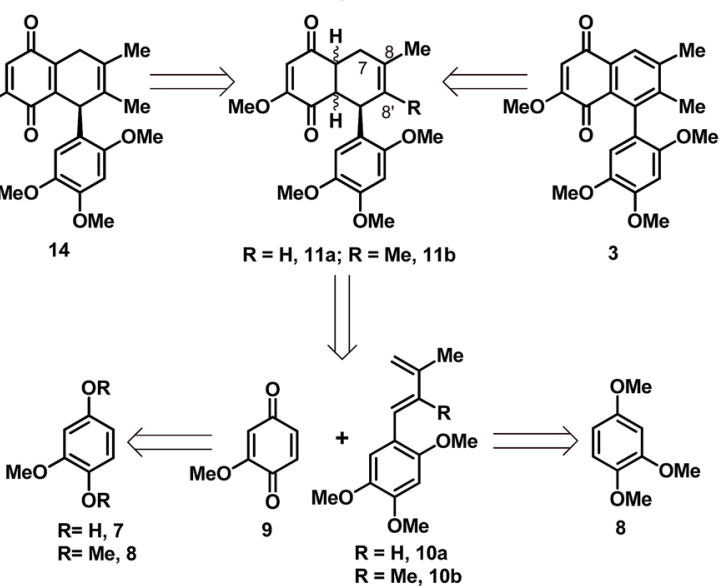

Scheme 1 Retrosynthetic plan towards 1, 3 and 5.
Scheme 1, which hinges on a Diels-Alder coupling of quinone 9 with either of the arylated diene $\mathbf{1 0 a} / \mathbf{b}$ to arrive at the $[4+2]$ cycloadduct $\mathbf{1 1 a} / \mathbf{b}$ in a highly regioselective fashion. While, the two coupling partner $\mathbf{9}$ and $\mathbf{1 0}$ were envisioned to be accessed through a common and readily available cheap starting material in the form of quinol 7 or its corresponding dimethyl ether 8. A 4-6 step synthetic manipulation on 8 was expected to offer the dienes $\mathbf{1 0 a} / \mathbf{b}$ in contrast to a single step access of $\mathbf{9}$ from $\mathbf{7 / 8}$ through known protocol. We anticipated the cycloadduct 11a/ b to hold immense potential in context of its elaboration to the targeted natural product. As a simple oxidation of the dihydroquinone in $\mathbf{1 1 b}$ to quinone would end up in the acquisition of 14 isomeric to 1 , having $\mathrm{C}_{8}=\mathrm{C}_{8^{\prime}}$ bond position instead of the $\mathrm{C}_{7}=\mathrm{C}_{8}$ bond position present in $\mathbf{1}$, whereas a straightforward oxidative aromatization in the quinone fused cyclohexene ring of 11b would lead to the natural quinone 3 . While, reductive methylation and then selective benzylic methylene oxidation at C-7 position of 11a followed by stereoselective installation of the methyl group at $\mathrm{C}-\mathrm{8}^{\prime}$ position was the route we had in mind to arrive at an intermediate like $\mathbf{1 2}$ for accessing 5. Similarly, reductive silylation and then selective benzylic methylene oxidation at C-7 position of $\mathbf{1 1 b}$ followed by stereoselective C-8, $\mathrm{C}-8^{\prime}$ double bond reduction was the route planned to access the functionally well placed intermediate like $\mathbf{1 3}$ which could be readily elaborated to either of the natural product $\mathbf{1}$ or $\mathbf{5}$ through some straightforward synthetic maneuvers.

Towards the realization of the retrosynthetic plan as outlined in Scheme 1, we commenced our foray with the synthesis of the two coupling partners 9 and 10a. The known quinone 9 (ref. 19) was accessed both via hypervalent iodine mediated oxidation on 8 as well as through $\mathrm{NaIO}_{4}$ mediated oxidation of 7 , with comparatively better yields observed in case of latter. While, the synthetic sequence towards the crafting of diene component 10a as depicted in Scheme 2 emanates from the known aldehyde 15 (ref. 20) obtained through a Vilsmeier-Haack formylation on 8. Wittig-Horner olefination of 15 with (carbethoxymethylene)triphenylphosphorane smoothly furnished the trans-cinnamate ester 16 exclusively, which on addition of excess methyllithium resulted in the formation of

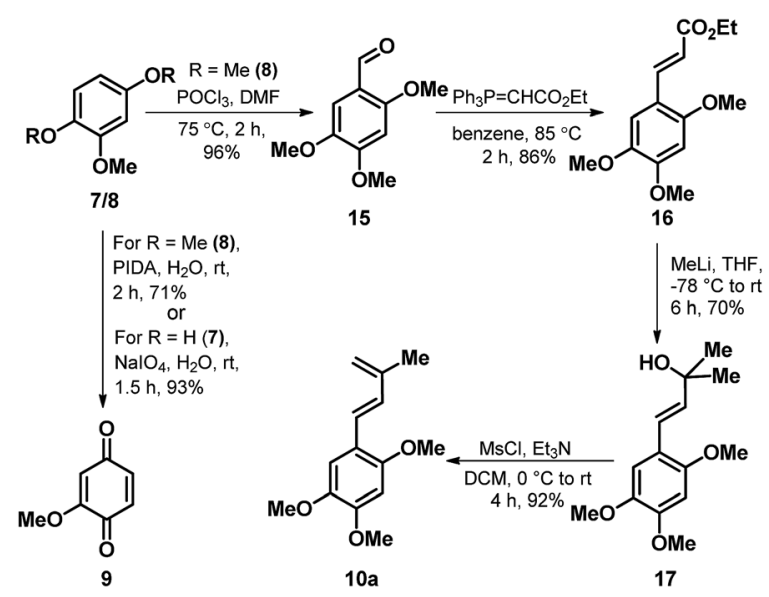

Scheme 2 Synthesis of the diene (10a) and dienophile (9). 
the cinnamyl alcohol 17. Then, a careful dehydration on 17 in the presence of mesyl chloride and $\mathrm{Et}_{3} \mathrm{~N}$ as the base furnished the desired diene 10a in excellent yield.

With both diene and dienophile in hand the next task was to execute the $[4+2]$ coupling between the two. Indeed, to our delight as highlighted in Scheme 3, the Diels-Alder coupling between 9 and 10a turned out to be quite eventful as the modest thermal activation of the diene and dienophilic component in dry toluene at $50{ }^{\circ} \mathrm{C}$ afforded a readily separable mixture of the bicyclic quinone 18 and naphthoquinone 19 in the ratio of $\sim 2.5$ : 1 and in 59\% overall yield. The formation of 18 and 19 is clearly attributable to the spontaneous concomitant partial and complete oxidation in the quinone fused cyclohexene ring of the $[4+2]$ cycloadduct 11a respectively. While the structure of 18 was secured through 2D NMR analysis with the key HMBC and nOe correlations as indicated in red and blue arrows respectively (Scheme 3), the close spectral resemblance of naphthoquinone 19 with that of gramineusquinone B (3) hinted it to be the desmethyl derivative of the natural product 3 .

Encouraged by the outcome of the $\mathrm{D}-\mathrm{A}$ reaction depicted in Scheme 3, we next turned our attention towards the functionalization of the quinone $\mathbf{1 8}$ for its elaboration to the natural products merrilliaquinone (1) and magnoshinin (5). In this regard, we thought of accessing $\mathbf{1 2} / \mathbf{1 3}$ by first oxidizing the C-7 methylene position in $\mathbf{1 8}$ to arrive at an enone for executing the stereoselective installation of the methyl group at C-8 ${ }^{\prime}$ position via Gilman-type addition after masking the quinone in the form of methyl/silyl protected quinol. However, failure in our attempts to oxidize the C-7 methylene position both on 18 as well as 18 derived 20, accessed via one-pot reductive methylation of 18 thwarted our plan of synthesizing 12/13. Nevertheless, in our attempts to relocate the double bond from C-8, C-8 ${ }^{\prime}$ to C-

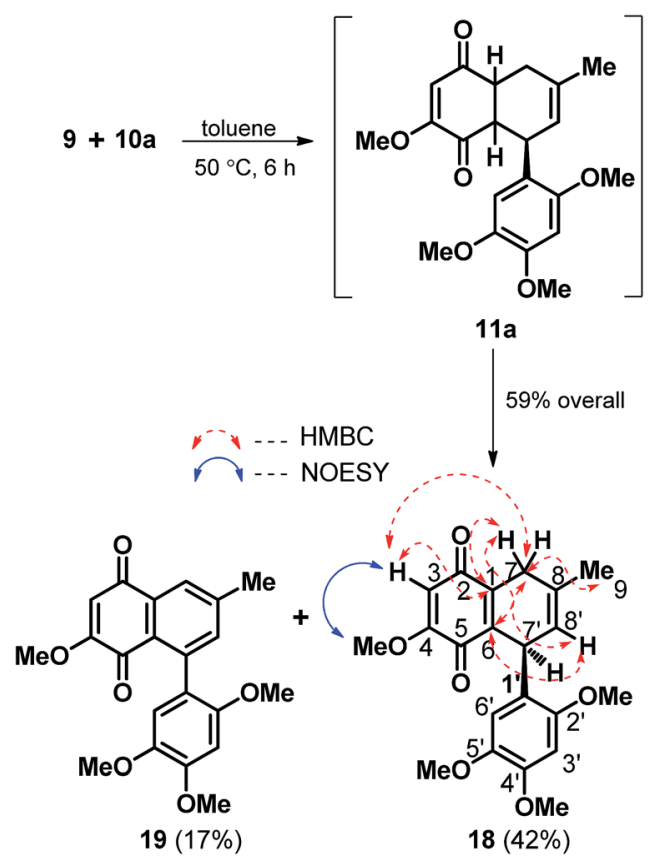

Scheme 3 Tandem [4 +2$]$ cycloaddition and oxidation leading to racemic 18 and desmethyl gramineusquinone $B(19)$.
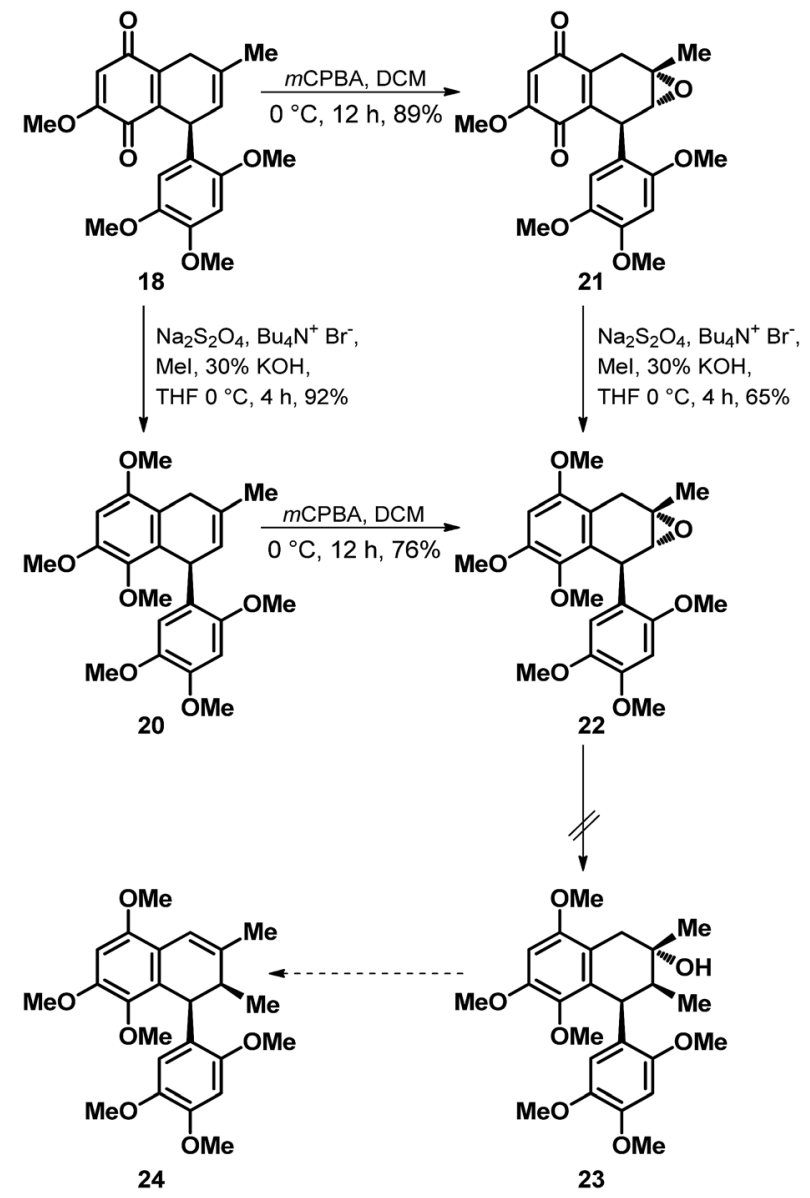

Scheme 4 Efforts towards the elaboration of 18 to racemic 2-epimagnoshinin (24).

7, C-8 position we explored a modified strategy as depicted in Scheme 4. Indeed, subjection of 18 to the $m$-CPBA mediated epoxidation offered the epoxy quinone 21 in a diastereoselective manner and in decent yield. But then, the nucleophilic methyl mediated epoxide ring opening on 22 accessed from 21 via reductive methylation as well as via diastereoselective epoxidation of 20 turned out to be a difficult proposition as it failed to offer the desired ring opened product 23 for its further elaboration to 2-epi-magnoshinin (24).

Undeterred by our failures in elaborating the cycloadduct 18 to any of the targeted natural product, we next thought of revisiting the strategy in order to access cycloadduct $\mathbf{1 1 b}$ with a preinstalled methyl group at $\mathrm{C}-\mathrm{8}^{\prime}$ position. In this context, through a similar synthetic sequence as earlier demonstrated for preparation of diene 10a (Scheme 2), the diene 10b was synthesized from 15 via the cinnamate ester 25 and tertiary alcohol 26 as depicted in Scheme 5. With access to diene 10b in good yield we readily executed its $[4+2]$ coupling with 9 under similar coupling condition as that used for 10a in Scheme 3, but to our surprise with observation of a slight different outcome in terms of product profile. Contrary to the $\mathrm{D}-\mathrm{A}$ reaction involving $10 \mathrm{a}$, the $\mathrm{D}-\mathrm{A}$ reaction in case of $\mathbf{1 0 b}$ afforded a mixture of quinone $\mathbf{1 4}$ and bicyclic quinol 27 in the ratio of $\sim 2.6: 1$ respectively and in an overall yield of $66 \%$. Though 14 could be carefully separated from 


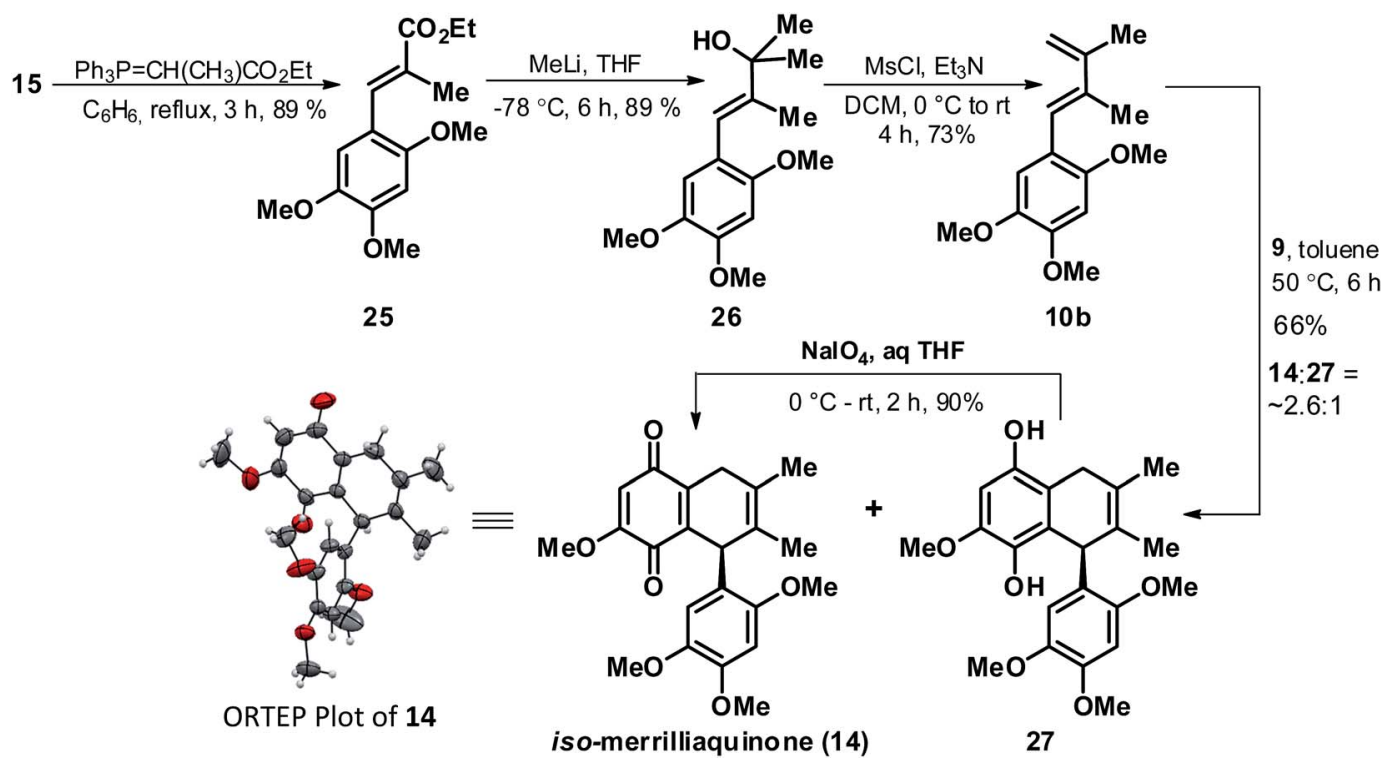

Scheme $5[4+2]$ cycloaddition of $10 \mathrm{~b}$ and 9 leading to racemic iso-merrilliaquinone.

27 but the tendency of the quinol 27 to readily undergo spontaneous partial conversion to the quinone form 14 made it difficult to isolate it in the purest form. However, it didn't turn out to be a serious concern as exposure of the mixture of $\mathbf{1 4}$ and 27 to $\mathrm{NaIO}_{4}$ afforded a single product 14 which was better serviceable in context of further elaboration to the targeted natural products. Further, the structure of $\mathbf{1 4}$ was secured through comparison of its spectral data $\left({ }^{1} \mathrm{H}\right.$ and $\left.{ }^{13} \mathrm{C} \mathrm{NMR}\right)$ with that of related quinone 18, however for sake of unambiguity we also confirmed the structure through X-ray crystallographic analysis. ${ }^{21}$ The ORTEP plot of $\mathbf{1 4}$ is as highlighted in Scheme 5. In view of the similar chemical constitution of the quinone $\mathbf{1 4}$ as that of targeted natural product (1), except for the position of the double bond in the quinone fused cyclohexene ring we presumed appropriate for quinone $\mathbf{1 4}$ to be referred as iso-merrilliaquinone.

Towards the end game, foremost keeping in mind the close proximity of $\mathbf{1 4}$ to natural product $\mathbf{3}$, the former was readily subjected to a DDQ mediated aromatization in the quinone fused cyclohexene ring to arrive at gramineusquinone B, 3 in good yields, Scheme 6 . The synthetic sample of 3 was found to be spectroscopically $\left({ }^{1} \mathrm{H}\right.$ and ${ }^{13} \mathrm{C}$ NMR) identical to the reported natural product. ${ }^{12}$ Then, efforts were channelized towards elaboration of 14 as well as 14 derived 28 (isomeric to magnoshinin, 5) to an intermediate like 12/13 in context of its elaboration to natural product $\mathbf{1}$ and $\mathbf{5}$ as per the retrosynthetic plan envisioned in Scheme 1. But this time again, all our investigated conditions proved ineffective in oxidizing the C-7 methylene position in $\mathbf{1 4}$ as well as the $\mathbf{1 4}$ derived 28. Also, attempts to isomerise the double bond position in $\mathbf{1 4}$ as well as 28 proved unfruitful. After repeatedly failing in our attempts to unsymmetrically functionalize the $\mathrm{C}_{8}=\mathrm{C}_{8^{\prime}}$ bond both in 14 and 28, we then executed a rather straightforward catalytic hydrogenation on iso-magnoshinin 28 with the hope of accessing the dihydro version of the natural product 5 . Indeed the double bond reduction on $\mathbf{2 8}$ turned out to be stereoselective offering

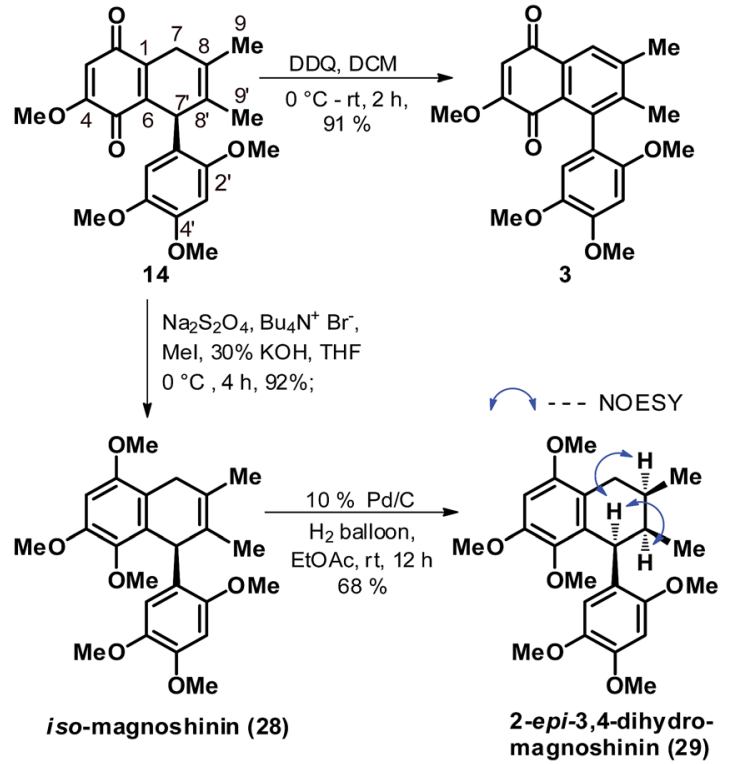

Scheme 6 Synthesis of racemic gramineusquinone B (3), iso-magnoshinin (28) and 2-epi-3,4-dihydro-magnoshinin (29).

29 in decent yields but deviant from the desired stereochemistry at C-8' position in context of 5. 2D NMR analysis of 28 confirmed the delivery of the two $\mathrm{H}$-atoms on the $\mathrm{C}_{8}=\mathrm{C}_{8^{\prime}}$ bond from the side opposite to the phenyl ring at the $\mathrm{C}^{-7^{\prime}}$ position and hinted 29 to be $8^{\prime}$-epi-7,8-dihydro-magnoshinin or 2-epi-3,4-dihydromagnoshinin as per the numbering given to the natural product in the isolation paper. ${ }^{\mathbf{1 4}}$

\section{Conclusions}

In conclusion, we have successfully demonstrated the syntheses of gramineusquinone B, iso-merrilliaquinone and iso- 
magnoshinin as well as 2-epi-3,4-dihydro-magnoshinin from readily accessible fragments through a straightforward DielsAlder strategy. Efforts are currently underway to overcome the difficulties encountered in the present route for the total syntheses of merrilliaquinone and magnoshinin which may eventually pave the way for other interested bioactive quinones and neolignans.

\section{Experimental}

All the reagents were purchased from Sigma-Aldrich and other commercial suppliers and used without further purification. While most of the desired solvents supplied by commercial suppliers were dried using the standard drying procedures. ${ }^{22}$ All nonaqueous reactions were executed under nitrogen atmosphere. Melting points were determined on a Buchi M-560 apparatus and are uncorrected. The ${ }^{1} \mathrm{H}$ and ${ }^{13} \mathrm{C}$ NMR spectra were recorded on 400 and $100 \mathrm{MHz}$ Bruker spectrometer respectively using TMS as an internal standard. The following abbreviations are used for spin multiplicity: $\mathrm{s}=$ singlet, $\mathrm{d}=$ doublet, $\mathrm{t}=$ triplet, $\mathrm{q}=$ quartet, $\mathrm{p}=$ quintet/pentet, $\mathrm{dd}=$ doublet of doublet, ddd $=$ doublet of doublet of doublet and $\mathrm{m}$ $=$ multiplet. The chemical shifts are reported as $\delta$ values (ppm) and the coupling constants $(J)$ values are reported in Hz. High Resolution Mass Spectra (HRMS) were obtained using electron spray ionization (ESI) technique and as TOF mass analyzer. IR spectra were recorded on a Bruker FT/IR-460 Plus spectrometer. Reactions monitoring were done using precoated $\mathrm{SiO}_{2}$-gel GF254 glass TLC plates while spot visualizations were done under UV light and spot developing stains like $p$-anisaldehyde or $\mathrm{KMnO}_{4}$. Purifications were done using column chromatography with 100-200 mesh size $\mathrm{SiO}_{2}$-gel as the stationary phase. Compound 9 (ref. 19) and 15 (ref. 20) were prepared according to the earlier reported procedures.

\section{(E)-1,2,4-Trimethoxy-5-(3-methylbuta-1,3-dien-1-yl)benzene} (10a)

To a solution of $17(1 \mathrm{~g}, 3.968 \mathrm{mmol})$ in dry DCM $(10 \mathrm{~mL}), 10 \mathrm{~mL}$ of triethylamine was added. The reaction mixture was then cooled to $-5{ }^{\circ} \mathrm{C}$ before adding mesyl chloride $(0.46 \mathrm{~mL}, 5.945$ $\mathrm{mmol}$ ) followed by DMAP ( $48.31 \mathrm{mg}, 0.396 \mathrm{mmol}$ ). The reaction mixture was then allowed to warm to rt and stirred for another $1.5 \mathrm{~h}$ until complete consumption of starting material and formation of a new spot was indicated by the TLC analysis. The reaction was worked up by diluting it with water followed by extraction in DCM $(4 \times 40 \mathrm{~mL})$. The organic layer after drying over $\mathrm{Na}_{2} \mathrm{SO}_{4}$ and then removal of the solvent under reduced pressure offered a crude oily residue which was purified by stirring the crude residue with $25-30 \%$ DCM for $30 \mathrm{~min}$. followed by decantation of the solvent and evaporation under reduced pressure to get the diene $10 \mathrm{a}(850 \mathrm{mg}, 3.628 \mathrm{mmol}$, 91.5\% yield) as an oil. IR (neat): $\nu_{\max } 2931,1512,1466,1398$, 1276, 1258, 1207, 1039, 757, $735 \mathrm{~cm}^{-1}$; ${ }^{1} \mathrm{H}$ NMR (400 MHz, $\left.\mathrm{CDCl}_{3}\right) \delta 7.04(\mathrm{~s}, 1 \mathrm{H}), 6.84(\mathrm{~d}, J=16.4 \mathrm{~Hz}, 1 \mathrm{H}), 6.75(\mathrm{~d}, J=$ $16.4 \mathrm{~Hz}, 1 \mathrm{H}) 6.50(\mathrm{~s}, 1 \mathrm{H}), 5.07$ (d, $J=1.2 \mathrm{~Hz}, 1 \mathrm{H}), 5.01(\mathrm{br} \mathrm{s}, 1 \mathrm{H})$, $3.90(\mathrm{~s}, 3 \mathrm{H}), 3.88(\mathrm{~s}, 3 \mathrm{H}), 3.84(\mathrm{~s}, 3 \mathrm{H}), 1.98(\mathrm{~s}, 3 \mathrm{H}) ;{ }^{13} \mathrm{C}$ NMR $(100$
$\left.\mathrm{MHz}, \mathrm{CDCl}_{3}\right) \delta 151.61,149.48,143.47,142.76,130.02,122.87$, 118.35, 115.96, 109.41, 97.82, 56.71, 56.52, 56.09, 18.73.

\section{Procedure for the Diels-Alder reaction of 9 and 10a}

To a solution of dienophile 9 (294 $\mathrm{mg}, 2.130 \mathrm{mmol})$ in toluene (5 $\mathrm{mL}$ ), diene 10a (797 mg, $3.408 \mathrm{mmol}$ ) was added and allowed to stir at $50{ }^{\circ} \mathrm{C}$ for $6 \mathrm{~h}$. On complete consumption of starting material by TLC analysis the reaction was worked up by evaporating out the entire toluene under reduced pressure and subjecting the resultant crude residue to $\mathrm{SiO}_{2}$ gel column chromatographic purification using petroleum ether/ethyl acetate $(7: 3)$ as the eluent to first isolate the partially oxidised DA adduct 18 (332 mg, $0.896 \mathrm{mmol}, 42 \%$ yield) followed by the aromatized naphthoquinone derivative 19 (135 mg, $0.366 \mathrm{mmol}, 17 \%$ ) with an overall yield of $59 \%$ for the D-A coupling.

\section{2-Methoxy-6-methyl-8-(2,4,5-trimethoxyphenyl)naphthalene- 1,4-(5H, 8H)-dione (18)}

Brown-red solid, mp: 138.6-139.4 ${ }^{\circ} \mathrm{C}$. IR (neat): $\nu_{\max }$ 2936, 1673, 1649, 1608, 1510, 1440, 1314, 1221, 1206, $1032 \mathrm{~cm}^{-1} ;{ }^{1} \mathrm{H}$ NMR $\left(400 \mathrm{MHz}, \mathrm{CDCl}_{3}\right) \delta 6.50(\mathrm{~s}, 1 \mathrm{H}), 6.45(\mathrm{~s}, 1 \mathrm{H}), 5.88(\mathrm{~s}, 1 \mathrm{H}), 5.48(\mathrm{~d}$, $J=2.0 \mathrm{~Hz}, 1 \mathrm{H}), 4.89\left(\mathrm{dd}, J_{1}=5.6 \mathrm{~Hz}, J_{2}=10.4 \mathrm{~Hz}, 1 \mathrm{H}\right), 3.86(\mathrm{~s}$, $3 \mathrm{H}), 3.83(\mathrm{~s}, 3 \mathrm{H}), 3.75(\mathrm{~s}, 3 \mathrm{H}), 3.73(\mathrm{~s}, 3 \mathrm{H}), 3.08(\mathrm{dd}$ appearing as $\mathrm{t}, J=7.0 \mathrm{~Hz}, 2 \mathrm{H}), 1.77(\mathrm{~s}, 3 \mathrm{H}) ;{ }^{13} \mathrm{C} \mathrm{NMR}\left(100 \mathrm{MHz}, \mathrm{CDCl}_{3}\right)$ $\delta 187.49,180.85,158.53,151.31,148.67,143.39,140.57,139.91$, 128.10, 123.18, 122.06, 113.25, 106.82, 98.81, 57.25, 56.92, 56.10 (2C), 35.25, 29.13, 22.70. HRMS (ESI) $m / z$ calcd for $\mathrm{C}_{21} \mathrm{H}_{23} \mathrm{O}_{6}(\mathrm{M}$ $+\mathrm{H})^{+}$: 371.1489; found: 371.1487 .

\section{2-Methoxy-6-methyl-8-(2,4,5-trimethoxyphenyl)naphthalene- 1,4-dione (19)}

Brown-red solid, mp: $167.3-168.4{ }^{\circ} \mathrm{C}$. IR (neat): $\nu_{\max } 2937,1683$, 1649, 1615, 1595, 1516, 1465, 1215, 1033, $852 \mathrm{~cm}^{-1}$; ${ }^{1} \mathrm{H}$ NMR $\left(400 \mathrm{MHz}, \mathrm{CDCl}_{3}\right) \delta 7.94(\mathrm{~d}, J=1.6 \mathrm{~Hz}, 1 \mathrm{H}), 7.31(\mathrm{~d}, J=1.5 \mathrm{~Hz}$, $1 \mathrm{H}), 6.68(\mathrm{~s}, 1 \mathrm{H}), 6.57(\mathrm{~s}, 1 \mathrm{H}), 6.10(\mathrm{~s}, 1 \mathrm{H}), 3.94(\mathrm{~s}, 3 \mathrm{H}), 3.84(\mathrm{~s}$, $6 \mathrm{H}), 3.65(\mathrm{~s}, 3 \mathrm{H}), 2.49(\mathrm{~s}, 3 \mathrm{H}) ;{ }^{13} \mathrm{C} \mathrm{NMR}\left(100 \mathrm{MHz}, \mathrm{CDCl}_{3}\right)$ $\delta 185.44,179.56,161.10,150.64,149.23,144.42,143.05,139.78$, 137.89, 133.07, 127.02, 126.47, 121.37, 113.07, 108.27, 97.37, 56.61, 56.36, 56.32, 56.20, 21.77. HRMS (ESI) $\mathrm{m} / \mathrm{z}$ calcd for $\mathrm{C}_{21} \mathrm{H}_{21} \mathrm{O}_{6}(\mathrm{M}+\mathrm{H})^{+}$: 369.1333; found: 369.1366 .

\section{5,7,8-Trimethoxy-3-methyl-1-(2,4,5-trimethoxyphenyl)-1,4- dihydronaphthalene (20)}

To a stirred solution of $18(20 \mathrm{mg}, 0.054 \mathrm{mmol})$ in THF $(2 \mathrm{~mL})$ containing $n$ - $\mathrm{Bu}_{4} \mathrm{NBr}(43.51 \mathrm{mg}, 0.135 \mathrm{mmol})$ at $0{ }^{\circ} \mathrm{C}$ were added $30 \%$ aq. $\mathrm{Na}_{2} \mathrm{~S}_{2} \mathrm{O}_{4}(2.5 \mathrm{~mL}, 4.310 \mathrm{mmol})$, MeI $(0.42 \mathrm{~mL}, 6.756$ $\mathrm{mmol})$ and aqueous $\mathrm{KOH}(1 \mathrm{~mL})$ sequentially. After $5 \mathrm{~min}$, the mixture was allowed to warm to rt, and stirring was continued for $1.5 \mathrm{~h}$ at the same temperature when complete consumption of starting material along with formation of a new spot was indicated by TLC analysis. The reaction was worked up by extracting it in ethyl acetate followed by drying of the separated organic phase over $\mathrm{Na}_{2} \mathrm{SO}_{4}$. Removal of the solvent under reduced pressure afforded a residue which was purified by $\mathrm{SiO}_{2}$ 
gel column chromatography using hexane/ethyl acetate $(7: 3)$ as the eluent to get $\mathbf{2 0}$ (20 mg, $0.050 \mathrm{mmol}, 92 \%$ yield) as an oil. IR (neat): $\nu_{\max } 2934,2836,1601,1507,1463,1337,1235,1204$, 1039, $829 \mathrm{~cm}^{-1}$; ${ }^{1} \mathrm{H}$ NMR (400 MHz, $\mathrm{CDCl}_{3}$ ) $\delta 6.54(\mathrm{~s}, 1 \mathrm{H}), 6.44$ $(\mathrm{s}, 1 \mathrm{H}), 6.28(\mathrm{~s}, 1 \mathrm{H}), 5.61-5.59(\mathrm{~m}, 1 \mathrm{H}), 5.17(\mathrm{~d}, J=4.0 \mathrm{~Hz}, 1 \mathrm{H})$, 3.87 (s, 3H), 3.86 (s, 3H), $3.84(\mathrm{~s}, 3 \mathrm{H}), 3.82(\mathrm{~s}, 3 \mathrm{H}), 3.62(\mathrm{~s}, 3 \mathrm{H})$, 3.29 (s, 3H), 3.22-3.11 (m, 2H), $1.78(\mathrm{~s}, 3 \mathrm{H}) ;{ }^{13} \mathrm{C}$ NMR $(100 \mathrm{MHz}$, $\left.\mathrm{CDCl}_{3}\right) \delta 152.46,150.92,150.73,147.71,143.31,140.45,132.70$, 129.34, 127.54, 122.90, 117.05, 113.30, 98.46, 95.56, 59.82, $57.21,56.78,56.28,56.10,55.67,35.12,28.89,23.25$. HRMS (ESI) $m / z$ calcd for $\mathrm{C}_{23} \mathrm{H}_{29} \mathrm{O}_{6}(\mathrm{M}+\mathrm{H})^{+}$: 401.1959; found: 401.1951 .

\section{5-Methoxy-1a-methyl-7-(2,4,5-trimethoxyphenyl)-1a,2,7,7a- tetrahydronaphtho[2,3-b] oxirene-3,6-dione (21)}

To a cooled solution of $18(15 \mathrm{mg}, 0.040 \mathrm{mmol})$ in DCM $(2 \mathrm{~mL})$, $m$-CPBA (9.3 $\mathrm{mg}, 0.053 \mathrm{mmol})$ was added portion wise and allowed to stir for $12 \mathrm{~h}$ at $0{ }^{\circ} \mathrm{C}$ until complete consumption of starting material along with formation of a new spot was indicated by TLC analysis. The reaction was worked up by evaporating DCM and the resultant crude residue was purified by $\mathrm{SiO}_{2}$ gel column chromatography using hexane/ethyl acetate $(3: 2)$ as the eluent to arrive at the epoxide 21 (14 mg, $0.036 \mathrm{mmol}$, $89 \%$ yield) as a pale yellow solid, mp: $139.7-140.8{ }^{\circ} \mathrm{C}$. IR (neat): $\nu_{\max } 2936,1674,1655,1611,1511,1461,1314,1221,1032,806$ $\mathrm{cm}^{-1} ;{ }^{1} \mathrm{H}$ NMR $\left(400 \mathrm{MHz}, \mathrm{CDCl}_{3}\right) \delta 6.76(\mathrm{~s}, 1 \mathrm{H}), 6.48(\mathrm{~s}, 1 \mathrm{H}), 5.85$ $(\mathrm{s}, 1 \mathrm{H}), 4.66(\mathrm{~d}, J=1.6 \mathrm{~Hz}, 1 \mathrm{H}), 3.85(\mathrm{~s}, 3 \mathrm{H}), 3.82(\mathrm{~s}, 3 \mathrm{H}), 3.80(\mathrm{~s}$, $3 \mathrm{H}), 3.73(\mathrm{~s}, 3 \mathrm{H}), 3.22\left(\mathrm{ddd}, J_{1}=1.2 \mathrm{~Hz}, J_{2}=2.4 \mathrm{~Hz}, J_{3}=20.0 \mathrm{~Hz}\right.$, $1 \mathrm{H}), 3.16(\mathrm{~s}, 1 \mathrm{H}), 2.68\left(\mathrm{dd}, J_{1}=2.4 \mathrm{~Hz}, J_{2}=20.0 \mathrm{~Hz}, 1 \mathrm{H}\right), 1.47(\mathrm{~s}$, $3 \mathrm{H}) ;{ }^{13} \mathrm{C}$ NMR $\left(100 \mathrm{MHz}, \mathrm{CDCl}_{3}\right) \delta 187.20,181.05,158.52$, $152.13,149.39,143.12,138.53,137.20,116.60,115.04,106.96$, 97.67, 61.44, 57.40, 56.79, 56.38, 56.18, 56.13, 37.58, 29.08, 22.57. HRMS (ESI) $\mathrm{m} / z$ calcd for $\mathrm{C}_{21} \mathrm{H}_{23} \mathrm{O}_{7}(\mathrm{M}+\mathrm{H})^{+}:$: 387.1438; found: 387.1423 .

\section{3,5,6-Trimethoxy-1a-methyl-7-(2,4,5-trimethoxyphenyl)-} 1a,2,7,7a-tetrahydronaphtho[2,3-b]oxirene (22)

The compound 22 was obtained in $76 \%$ yield $(11.9 \mathrm{mg}, 0.028$ mmol) via epoxidation of 20 ( $15 \mathrm{mg}, 0.038 \mathrm{mmol})$ using $m$-CPBA (8.0 $\mathrm{mg}, 0.048 \mathrm{mmol}$ ) and employing similar epoxidation procedure as that described for 21 . Alternatively it was also obtained in $65 \%$ yield $(7.0 \mathrm{mg}, 0.017 \mathrm{mmol})$ by reductive methylation of 21 (10 mg, $0.026 \mathrm{mmol})$ using $30 \%$ aq. $\mathrm{Na}_{2} \mathrm{~S}_{2} \mathrm{O}_{4}$ (1.26 mL, $2.172 \mathrm{mmol})$, MeI (0.2 mL, $3.238 \mathrm{mmol}$ ) and aqueous $\mathrm{KOH}(1 \mathrm{~mL})$ employing similar procedure as that described for 20. IR (neat): $\nu_{\max } 2924,2851,1680,1650,1612,1511,1462$, 1214, 1034, $850 \mathrm{~cm}^{-1} ;{ }^{1} \mathrm{H}$ NMR (400 MHz, $\left.\mathrm{CDCl}_{3}\right) \delta 6.56(\mathrm{~s}, 1 \mathrm{H})$, $6.42(\mathrm{~s}, 1 \mathrm{H}), 6.31(\mathrm{~s}, 1 \mathrm{H}), 5.19(\mathrm{~d}, J=2.0 \mathrm{~Hz}, 1 \mathrm{H}), 3.87(\mathrm{~s}, 3 \mathrm{H})$, $3.86(\mathrm{~s}, 3 \mathrm{H}), 3.84(\mathrm{~s}, 3 \mathrm{H}), 3.81(\mathrm{~s}, 3 \mathrm{H}), 3.64(\mathrm{~s}, 3 \mathrm{H}), 3.42(\mathrm{~d}, J=$ $19.0 \mathrm{~Hz}, 1 \mathrm{H}), 3.41$ (s, 3H), 3.25 (dd, $J=2.0,1.0 \mathrm{~Hz}, 1 \mathrm{H}), 2.78$ (d, $\left.=18.0 \mathrm{~Hz}, 1 \mathrm{H}), 1.43(\mathrm{~s}, 3 \mathrm{H}) ;{ }^{13} \mathrm{C} \mathrm{NMR} \mathrm{(100} \mathrm{MHz,} \mathrm{CDCl}_{3}\right)$ $\delta 153.07,151.67,151.32,148.63,143.13,141.06,130.12,121.48$, 114.06, 113.78, 98.10, 96.06, 62.08, 60.26, 57.02, 56.89, 56.76, $56.16,56.09,55.74,35.55,28.51,22.93$. HRMS (ESI) $\mathrm{m} / \mathrm{z}$ calcd for $\mathrm{C}_{23} \mathrm{H}_{29} \mathrm{O}_{7}(\mathrm{M}+\mathrm{H})^{+}$: 417.1908; found: 417.1941.
(E)-1-(2,3-Dimethylbuta-1,3-dien-1-yl)-2,4,5-trimethoxybenzene (10b)

To a solution of 26 (598 mg, $2.248 \mathrm{mmol})$ in dry DCM $(10 \mathrm{~mL})$, $10 \mathrm{~mL}$ of triethylamine was added. The reaction mixture was then cooled to $-5{ }^{\circ} \mathrm{C}$ before adding mesyl chloride $(0.26 \mathrm{~mL}$, $3.372 \mathrm{mmol}$ ) followed by DMAP $(27.4 \mathrm{mg}, 0.224 \mathrm{mmol})$. The reaction mixture was then allowed to warm to $\mathrm{rt}$ and stirred for another $2 \mathrm{~h}$ until complete consumption of starting material and formation of a new spot was indicated by the TLC analysis. The reaction was worked up by diluting it with water and extracting in DCM $(4 \times 40 \mathrm{~mL})$ followed by drying of the separated organic phase over $\mathrm{Na}_{2} \mathrm{SO}_{4}$. Removal of the solvent under reduced pressure afforded a residue which was purified by column chromatography using hexane/ethyl acetate $(8: 2)$ as the eluent to get 10b (408 mg, $1.643 \mathrm{mmol}, 73 \%$ yield) as an oil. IR (neat): $\nu_{\max } 2947,2833,1605,1511,1464,1316,1302,1206$, 1177, 1036, $875 \mathrm{~cm}^{-1}$; ${ }^{1} \mathrm{H}$ NMR (400 MHz, $\left.\mathrm{CDCl}_{3}\right) \delta 6.79(\mathrm{~s}, 1 \mathrm{H})$, $6.66(\mathrm{~s}, 1 \mathrm{H}), 6.53(\mathrm{~s}, 1 \mathrm{H}), 5.15(\mathrm{~s}, 1 \mathrm{H}), 5.03(\mathrm{~s}, 1 \mathrm{H}), 3.91(\mathrm{~s}, 3 \mathrm{H})$, $3.84(\mathrm{~s}, 3 \mathrm{H}), 3.81(\mathrm{~s}, 3 \mathrm{H}), 2.06(\mathrm{~d}, J=0.4 \mathrm{~Hz}, 3 \mathrm{H}) 1.99$ (d, $J=$ $0.8 \mathrm{~Hz}, 3 \mathrm{H}) ;{ }^{13} \mathrm{C} \mathrm{NMR}\left(100 \mathrm{MHz}, \mathrm{CDCl}_{3}\right) \delta 151.90,148.68,144.97$, $142.47,136.24,122.65,119.02$, 114.72, 112.55, 97.50, 56.66, $56.53,56.12,21.08,15.54$. HRMS (ESI) $m / z$ calcd for $\mathrm{C}_{15} \mathrm{H}_{21} \mathrm{O}_{3}(\mathrm{M}$ $+\mathrm{H})^{+}:$249.1485; found: 249.1460 .

\section{2-Methoxy-6,7-dimethyl-8-(2,4,5-trimethoxyphenyl) naphthalene-1,4-(5H,8H)-dione (iso-merrilliaquinone, 14)}

To a solution of dienophile $9(20 \mathrm{mg}, 0.145 \mathrm{mmol})$ in toluene, diene $10 \mathrm{~b}$ (58 $\mathrm{mg}, 0.232 \mathrm{mmol}$ ) was added and allowed to stir at $50{ }^{\circ} \mathrm{C}$ for $6 \mathrm{~h}$. On complete consumption of the dienophile and with formation of two new spots of 14 and 26 by TLC analysis, the reaction was worked up by evaporating out the entire toluene under reduced pressure. To the resultant crude residue was then added $\mathrm{NaIO}_{4}(19.9 \mathrm{mg}, 0.093 \mathrm{mmol})$ in aq. THF $(1.5$ $\mathrm{mL}$ ) at $0{ }^{\circ} \mathrm{C}$. The reaction was allowed to warm to rt over $2 \mathrm{~h}$ until the complete conversion of mixture of $\mathbf{1 4}$ and 26 to a single spot of 14 was indicated by TLC analysis. The reaction was worked by extracting it in EtOAc $(4 \times 15 \mathrm{~mL})$, washing the organic phase with brine and drying over $\mathrm{Na}_{2} \mathrm{SO}_{4}$. Removal of the solvent under reduced pressure followed by purification of the crude residue by $\mathrm{SiO}_{2}$-gel column chromatography using petroleum ether/ethyl acetate (7:3) as the eluent afforded $14(32.8 \mathrm{mg}$, $0.085 \mathrm{mmol}, 59 \%$ overall yield) as an orange solid, mp: 197.8$198.3{ }^{\circ}$ C. IR (neat): $\nu_{\max } 2935,2851,1674,1652,1636,1609$, 1512, 1351, 1227, $1033 \mathrm{~cm}^{-1} ;{ }^{1} \mathrm{H}$ NMR (400 MHz, $\left.\mathrm{CDCl}_{3}\right) \delta 6.49$ $(\mathrm{s}, 1 \mathrm{H}), 6.47(\mathrm{~s}, 1 \mathrm{H}), 5.84(\mathrm{~s}, 1 \mathrm{H}), 4.76(\mathrm{t}, J=5.6 \mathrm{~Hz}, 1 \mathrm{H}), 3.88(\mathrm{~s}$, $3 \mathrm{H}), 3.83(\mathrm{~s}, 3 \mathrm{H}), 3.73(\mathrm{~s}, 6 \mathrm{H}), 3.22-3.08(\mathrm{~m}, 2 \mathrm{H}), 1.76(\mathrm{~s}, 3 \mathrm{H})$, $1.56(\mathrm{~s}, 3 \mathrm{H}) ;{ }^{13} \mathrm{C}$ NMR $\left(100 \mathrm{MHz}, \mathrm{CDCl}_{3}\right) \delta 187.64,180.95$, 158.42 , 151.95, 148.62, 143.30, 140.50, 139.96, 126.81, 122.85, 121.59, 113.36, 106.71, 98.65, 57.46, 56.73, 56.08, 56.01, 39.47, $31.07,18.51,16.20$. HRMS (ESI) $m / z$ calcd for $\mathrm{C}_{22} \mathrm{H}_{25} \mathrm{O}_{6}(\mathrm{M}+\mathrm{H})^{+}$: 385.1646; found: 385.1675 .

\section{Gramineusquinone B (3)}

To stirred solution of $14(10 \mathrm{mg}, 0.026 \mathrm{mmol})$ in DCM (1 mL) at $0{ }^{\circ} \mathrm{C}$, DDQ $(5.9 \mathrm{mg}, 0.026 \mathrm{mmol})$ was added. The reaction 
mixture was then allowed to warm to rt and stirred for another $5 \mathrm{~h}$ until complete consumption of starting material and formation of a new spot was indicated by the TLC analysis. The reaction was worked up by removing the solvent under reduced pressure and then subjecting the resultant residue to $\mathrm{SiO}_{2}$ gel column chromatographic purification using hexane/ethyl acetate $(7: 3)$ as the eluent to arrive at $3(9 \mathrm{mg}, 0.023 \mathrm{mmol}$, 91\% yield) as a red solid, mp: $172.6-173.3{ }^{\circ} \mathrm{C}$. IR (neat): $\nu_{\max }$ 2937, 2842, 1685, 1648, 1617, 1517, 1213, 1085, 1031, 856, $\mathrm{cm}^{-1}$; ${ }^{1} \mathrm{H}$ NMR (400 MHz, $\left.\mathrm{CDCl}_{3}\right) \delta 7.96(\mathrm{~s}, 1 \mathrm{H}), 6.63(\mathrm{~s}, 1 \mathrm{H}), 6.40(\mathrm{~s}$, $1 \mathrm{H}), 6.06(\mathrm{~s}, 1 \mathrm{H}), 3.95(\mathrm{~s}, 3 \mathrm{H}), 3.80(\mathrm{~s}, 3 \mathrm{H}), 3.76(\mathrm{~s}, 3 \mathrm{H}), 3.65(\mathrm{~s}$, $\left.3 \mathrm{H}), 2.45(\mathrm{~s}, 3 \mathrm{H}), 2.01(\mathrm{~s}, 3 \mathrm{H}) ;{ }^{13} \mathrm{C} \mathrm{NMR} \mathrm{(100} \mathrm{MHz,} \mathrm{CDCl}_{3}\right)$ $\delta 185.52,179.83,160.77,150.39,148.94,143.80,143.76,143.63$, 139.41, 130.74, 127.21, 127.04, 120.48, 112.72, 108.03, 97.91, $56.57,56.43,56.23,56.16,21.47,16.92$. HRMS (ESI) $\mathrm{m} / \mathrm{z}$ calcd for $\mathrm{C}_{22} \mathrm{H}_{23} \mathrm{O}_{6}(\mathrm{M}+\mathrm{H})^{+}$: 383.1489; found: 383.1481.

\section{5,7,8-Trimethoxy-2,3-dimethyl-1-(2,4,5-trimethoxyphenyl)-1,4- dihydronaphthalene (iso-magnoshinin, 28)}

Reductive methylation on $14(20 \mathrm{mg}, 0.052 \mathrm{mmol})$ using $30 \%$ aq. $\mathrm{Na}_{2} \mathrm{~S}_{2} \mathrm{O}_{4}(2.5 \mathrm{~mL}, 4.310 \mathrm{mmol}), \mathrm{MeI}(0.42 \mathrm{~mL}, 6.756 \mathrm{mmol})$ and aqueous $\mathrm{KOH}(1 \mathrm{~mL})$ through similar procedure as described for preparation of 20, afforded compound 28 (20 mg, $0.048 \mathrm{mmol}, 92 \%$ yield) as pale yellow solid. IR (neat): $\nu_{\max } 2932$, 1602, 1509, 1462, 1439, 1336, 1316, 1238, 1203, $1033 \mathrm{~cm}^{-1} ;{ }^{1} \mathrm{H}$ NMR $\left(400 \mathrm{MHz}, \mathrm{CDCl}_{3}\right) \delta 6.51(\mathrm{~s}, 1 \mathrm{H}), 6.41(\mathrm{~s}, 1 \mathrm{H}), 6.40(\mathrm{~s}, 1 \mathrm{H})$, 5.04 (br s, 1H), 3.87 (s, 3H), 3.85 (s, 3H), 3.84 (s, 3H), $3.81(\mathrm{~s}, 3 \mathrm{H})$, $3.64(\mathrm{~s}, 3 \mathrm{H}), 3.32(\mathrm{~s}, 3 \mathrm{H}), 3.30(\mathrm{br} \mathrm{s}, 2 \mathrm{H}), 1.78(\mathrm{~s}, 3 \mathrm{H}), 1.64(\mathrm{~s}, 3 \mathrm{H})$; ${ }^{13} \mathrm{C} \mathrm{NMR}\left(100 \mathrm{MHz}, \mathrm{CDCl}_{3}\right) \delta 152.27,151.23,150.78,147.61$, 143.20, 140.03, 134.46, 127.73, 127.11, 122.74, 116.70, 113.73, 97.90, 95.21, 59.81, 56.96, 56.55, 56.22, 56.04, 55.68, 39.47, $30.98,19.03,16.66$. HRMS (ESI) $m / z$ calcd for $\mathrm{C}_{24} \mathrm{H}_{34} \mathrm{NO}_{6}(\mathrm{M}+$ $\left.\mathrm{NH}_{4}\right)^{+}:$432.2381; found: 432.2353 .

\section{5,7,8-Trimethoxy-2,3-dimethyl-1-(2,4,5-trimethoxyphenyl)- 1,2,3,4-tetrahydronaphthalene (2-epi-3,4-dihydro- magnoshinin, 29)}

To stirred solution of 28 (16 mg, $0.0386 \mathrm{mmol})$ in $\mathrm{MeOH}(1 \mathrm{~mL})$ was added $10 \% \mathrm{Pd} / \mathrm{C}(1.6 \mathrm{mg})$. The mixture was then allowed to stir at room temperature under hydrogen balloon pressure for $6 \mathrm{~h}$ until complete consumption of starting material was indicated by TLC analysis. The reaction mixture was then filtered through celite, washed with EtOAc $(4 \times 5 \mathrm{~mL})$ and the filtrate was concentrated under reduced pressure. The resultant crude residue was purified by flash column chromatography (petroleum ether/EtOAc $=8: 2$ ) on silica gel to afford the desired 2epi-3,4-dihydro-magnoshinin, $29(11 \mathrm{mg}, 0.026 \mathrm{mmol}, 68 \%$ yield). IR (neat): $\nu_{\max } 2932,2834,1596,1509,1462,1395,1333$, 1233, 1204, $1039 \mathrm{~cm}^{-1} ;{ }^{1} \mathrm{H}$ NMR (400 MHz, $\left.\mathrm{CDCl}_{3}\right) \delta 6.56(\mathrm{~s}, 1 \mathrm{H})$, $6.42(\mathrm{~s}, 1 \mathrm{H}), 6.23(\mathrm{~s}, 1 \mathrm{H}), 4.80(\mathrm{~d}, J=6.0 \mathrm{~Hz}, 1 \mathrm{H}), 3.87(\mathrm{~s}, 3 \mathrm{H})$, $3.86(\mathrm{~s}, 3 \mathrm{H}), 3.84(\mathrm{~s}, 3 \mathrm{H}), 3.79(\mathrm{~s}, 3 \mathrm{H}), 3.60(\mathrm{~s}, 3 \mathrm{H}), 3.20(\mathrm{~s}, 3 \mathrm{H})$, $2.62\left(\mathrm{dd}, J_{1}=4.5 \mathrm{~Hz}, J_{2}=17.0 \mathrm{~Hz}, 1 \mathrm{H}\right), 2.29\left(\mathrm{ddd}, J_{1}=1.2 \mathrm{~Hz}, J_{2}\right.$ $\left.=12.0 \mathrm{~Hz}, J_{3}=17.0, \mathrm{~Hz}, 1 \mathrm{H}\right), 2.14-2.08(\mathrm{~m}, 1 \mathrm{H}), 1.97-1.92(\mathrm{~m}$, $1 \mathrm{H}), 1.06$ (d, $J=7.0 \mathrm{~Hz}, 3 \mathrm{H}), 0.52(\mathrm{~d}, J=7.0 \mathrm{~Hz}, 3 \mathrm{H}) ;{ }^{13} \mathrm{C} \mathrm{NMR}$ $\left(100 \mathrm{MHz}, \mathrm{CDCl}_{3}\right) \delta 152.56,151.04,150.84,146.97,142.35$, 142.16 , 133.84, 126.26, 120.45, 113.80, 98.11, 95.64, 59.59,
57.28, 56.57 (2C), 56.11, 55.64, 40.31, 35.91, 32.80, 26.60, 19.61, 10.00. HRMS (ESI) $\mathrm{m} / z$ calcd for $\mathrm{C}_{24} \mathrm{H}_{36} \mathrm{NO}_{6}\left(\mathrm{M}+\mathrm{NH}_{4}\right)^{+}$: 434.2537; found: 434.2571 .

\section{Acknowledgements}

D. K. is grateful to UGC, India for the Junior Research Fellowship (JRF). T. K. thank IIT Bhubaneswar for the financial and infrastructural support. DST, SERB (EMR/2014/000826) is also acknowledged for providing funding to the lab.

\section{Notes and references}

1 Y. H. Liu, Flora Republicae Popularis Sinicae, Science Press, Beijing, 1996, vol. 30, p. 227.

2 For a review please refer: Y. Fukuyama and J.-M. Huang, Stud. Nat. Prod. Chem., 2005, 32, 395-427 and ref. cited therein.

3 J. M. Huang, Y. Fukuyama, C. S. Yang, H. Minami and M. Tanaka, Chem. Pharm. Bull., 2000, 48, 657-659.

4 M. Kubo, C. Okada, J.-M. Huang, K. Harada, H. Hioki and Y. Fukuyama, Org. Lett., 2009, 11, 5190-5193.

5 J.-M. Huang, R. Yokoyama, C.-S. Yang and Y. Fukuyama, J. Nat. Prod., 2001, 64, 428-431.

6 For few selected synthesis of merrilactone A please refer: $(a)$ V. B. Birman and S. J. Danishefsky, J. Am. Chem. Soc., 2002, 124, 2080-2081; (b) M. Inoue, T. Sato and M. Hirama, $J$. Am. Chem. Soc., 2003, 125, 10772-10773; (c) G. Mehta and S. R. Singh, Angew. Chem., Int. Ed., 2006, 45, 953-955; (d) W. He, J. Huang, X. F. Sun and A. J. Frontier, J. Am. Chem. Soc., 2007, 129, 498-499; (e) W. He, J. Huang, X. F. Sun and A. J. Frontier, J. Am. Chem. Soc., 2008, 130, 300-308.

7 For few selected approaches towards 11-0-debenzoyl tashironin please refer: (a) A. Polara, S. P. Cook and S. J. Danishefsky, Tetrahedron Lett., 2008, 49, 5906-5908; (b) G. Mehta and P. Maity, Tetrahedron Lett., 2011, 52, 1753-1756; (c) G. Mehta and P. Maity, Tetrahedron Lett., 2011, 52, 1749-1752.

8 For few selected approaches towards jiadifenolide please see (a) Y. Shen, L. Li, Z. Pan, Y. Wang, J. Li, K. Wang, X. Wang, Y. Zhang, T. Hu and Y. Zhang, Org. Lett., 2015, 17, 54805483; (b) H.-H. Lu, M. D. Martinez and R. A. Shenvi, Nat. Chem., 2015, 7, 604-607; (c) J. Xu, L. Trzoss, W. K. Chang and E. A. Theodorakis, Angew. Chem., Int. Ed., 2011, 50, 3672-3676; (d) G. Mehta, H. M. Shinde and R. Senthil Kumaran, Tetrahedron Lett., 2012, 53, 4320-4323.

9 X. Tian, R. Yue, S. Zhang, Y. Shen, J. Ye, L. Shan, H. Li, B. Wen, X. Xu and W. Zhang, Eur. J. Org. Chem., 2014, 4753-4758.

10 X. Tian, L. Li, J. Pei, R. Yue, X. Fang, J. Zhang, W. He, L. Shan, Y. Shen and W. Zhang, RSC Adv., 2015, 5, 75857-75862.

11 Y. Lu, Y. Xue, S. Chen, H. Zhu, J. Zhang, X.-N. Li, J. Wang, J. Liu, C. Qi, G. Du and Y. Zhang, Sci. Rep., 2016, 6, 1-10.

12 S. Y. Lee, E. Moon, S. Y. Kim, S. U. Choi and K. R. Lee, Biosci., Biotechnol., Biochem., 2013, 77, 276-280.

13 N.-Y. Chen, J. Shi and T. Chen, Planta Med., 2000, 66, 187188. 
14 T. Kikuchi, S. Kadota, K. Yanada, K. Tanaka, K. Watanabe, M. Yoshizaki, T. Yokoi and T. Shingu, Chem. Pharm. Bull, 1983, 31, 1112-1114.

15 D.-P. Qin, X.-L. Feng, W.-Y. Zhang, H. Gao, X.-R. Cheng, W.-X. Zhou, Y. Yu and X.-S. Yao, RSC Adv., 2017, 7, 85128520 .

16 For the synthesis of magnoshinin and other selected lignan synthesis please refer: (a) S. Kadota, K. Tsubono, K. Makino, M. Takeshita and T. Kikuchi, Tetrahedron Lett., 1987, 28, 2857-2860; (b) S.-I. Yoshida, T. Ogiku, H. Ohmizu and T. Iwasaki, Synlett, 1994, 11, 895-898; (c) B. L. Yvon, P. K. Datta, T. N. Le and J. L. Charlton, Synthesis, 2001, 10, 1556-1560; (d) Q. Xiao, J. J. Jackson, A. Basak, J. M. Bowler, B. G. Miller and A. Zakarian, Nat. Chem., 2013, 5, 410-416.
17 G. Mehta, T. B. Khan and S. Y. C. Kumar, Tetrahedron Lett., 2010, 51, 5116-5119.

18 G. Mehta and T. B. Khan, Tetrahedron Lett., 2010, 51, 65906593.

19 (a) K. A. Parker, D. M. Spero and K. A. Koziski, J. Org. Chem., 1987, 52, 183-188; (b) H. Tohma, H. Morioka, Y. Harayama, M. Hashizume and Y. Kita, Tetrahedron Lett., 2001, 42, 68996902.

20 Y.-L. Lin, C.-S. Wu, S.-W. Lin, J.-L. Huang, Y.-S. Sun and D.-Y. Yang, Bioorg. Med. Chem., 2002, 10, 685-690.

21 CCDC 1548143 contain the crystallographic information for 14. $\dagger$

22 D. L. F. Armarego, D. D. Perrin, Purification of Laboratory Chemicals, IV edn, 1996. 